\title{
PRINCIPLES OF MODERATION IN ISLAMIC POLITICS
}

\author{
Syaripudin \\ UIN Raden Intan Lampung \\ basyarsyarif@gmail.com
}

\begin{abstract}
Abstrak
Sebagai agama yang diwahyukan, Allah menyatakan Islam sebagai agama khiyar (yang terpilih dan terbaik) dengan rekomendasi terbaik di sisi-Nya yang menempatkan pengikutnya sebagai sebaik-baik ummat, dan wasathon ummah yang memiliki karakter yang adil dan toleran. Islam dalam posisi ini sebagai "wasathiyyah" (moderasi) yang berarti di posisi tengah, seimbang, adil, toleran, tidak ekstrim di satu sisi dan selaras dengan prinsip "rabbaniyah". Makna wasathiyyah dalam ta' rif al-wasathiyah mencakup pilihan yang adil, pamungkas, terbaik dan seimbang antara dua titik berlawanan yang berlawanan. Islam moderat adalah konsep Islam yang tidak condong ke kiri atau kanan, tetapi jalan lurus dan umat Islam dinyatakan sebagai moderat, orang-orang terbaik yang akan menjadi saksi dan pionir perdamaian dan perbaikan dunia. Islam yang moderat dapat dipahami sebagai pandangan atau sikap yang selalu berusaha mengambil posisi tengah dari dua sikap yang berlawanan dan dibesar-besarkan sehingga salah satu dari dua sikap tersebut tidak mendominasi satu sisi. Dengan kata lain, seorang Muslim moderat adalah seorang Muslim yang memberikan nilai yang tepat dan seimbang untuk dua pemikiran atau sikap yang berlawanan. Karena manusia, siapa pun dia, tidak mampu melarikan diri dari pengaruh dan bias karena selalu ada pengaruh tradisi, pikiran, keluarga atau waktu dan tempat dalam hidupnya. Tidak mungkin untuk mewakili atau menawarkan moderasi penuh di dunia nyata, hanya Tuhan yang dapat melakukannya.
\end{abstract}

Kata kunci: Moderasi, Islam

\begin{abstract}
As a revealed religion, Allah declared Islam as the khiyar religion (the chosen and the best) with the best accreditation in His side which places its followers as khoiru ummah, and wasathon ummah who has a fair and tolerant character. Yusuf Qardhawy interpreted Islam in this position as "wasathiyyah" (moderation) which means in the middle position, balanced, fair, tolerant, not extreme on one side and harmony with guiding principle "rabbaniyah". The meaning of wasathiyyah in ta'rif al-wasathiyahtheory covers fair, ultimate, best and balanced choice between two contradictory opposite points. Moderate Islam is a concept of Islam which does not lean to the left or right, but the straight path (shiroth mustaqim) and the Muslims are declared as moderates, the best people who will be the witnesses and pioneers of the world peace and betterment.Moderate Islamcan be understood as a view or an attitude that always tries to take the middle position of two opposite and exaggerated attitudes so that one of the two attitudes does not dominate one side. In other words, a moderate Muslim is a Muslim who gives proper and balanced value for two opposite thoughts or attitudes. Since man, whoever he is, is incapable of escaping himself from influence and bias as there is always influence of tradition, thought, family or time and place in his life. It is impossible to represent or offer full moderation in the real world, only God can do that.
\end{abstract}

Key words: Moderation, Islam 


\section{Introduction}

Islam is identical with eternal and universal treatises, delegated and gradually awaited and granted almost to all messengers of Allah, the Prophets and the Apostles. In succession, Allah introduces the word Islam to Abraham, Isma'il, Ishaq, Ya'qub, Asbath, Moses, 'Isa and other Anbiya'. ${ }^{1}$ Here Islam is declared as His best Shibghoh (dye) that distinguishes it from Judaism and Christianity. As a revealed religion, Islam is revealed by Allah as the khiyar religion (the chosen and the best) with the best accreditation in His side which places its followers as khoiru ummah, and ummat wasathon (QS.2: 143) which has fair and tolerant character. Yusuf Qardhawy (al-Khosho'is al-'Ammah, 1983: 131) interpreted this Islamic position as "wasathiyyah" (moderation) that is in the middle position, balanced, fair, tolerant, not extreme on one side/party and harmony with "rabbaniyah" guiding principle (taken from God and preserved its authenticity). Isnan Anshory (Alwasathiyah, 2014: 3) defines the meaning of wasathiyyah etymologically, that the word is taken from ta'rif al-wasathiyah which means fair, main, best and balanced choice between two opposite and contradictory points. Moderate Islam is a concept of Islam that does not lean to the left or right but the straight path (shiroth mustaqim) and the Muslims are declared as moderates (wasathan), the best people who will be witnesses and pioneers for world peace and betterment.

Furthermore, moderation in Islam can be understood as a view or attitude that always tries to take the middle position of two opposite and exaggerated attitudes so that one of the two attitudes does not dominate each other. In other words, a moderate Muslim is a Muslim who gives balanced and proper value or aspect to both partswithout exceeding their right. Since man - whoever he is -is incapable of escaping himself from influence and bias as there is always influence of tradition, thought, family or time and place in his life. It is impossible to represent or present full moderation in the real world. The One who can do that is only God.2

Based on the above issues, moderation or tolerance is one of the core of Islamic teachings that plays role in overcoming the recent problems such as the rise of radicalization, violence in the name of religion, accusing other parties as infidels, extremism and excessive fanaticism (hizbiyyah). This study discusses the dimensions of Islamic teachings about moderation as a conceptual and contextual force in caring for egalitarian social order and facing the dynamic of horizontal and vertical conflicts that are still common in our society which is caused by various factors that are political, economic, ethnic or intolerant in religious life in the context of nation and state.

1See QS al-Baqarah verse 127-136

2See Yusuf al-Qaradhawi, Kalimaat fi al-Wasatiyyah al-Islamiyyah wa Ma'alimuha, (Kuwait: al-Markaz al-Alami Lilwasatiyyah, 2007). 
In fact, the principle of moderation contained in the teachings of Islam itself had been exemplified by the Prophet in preparing and building a society in Medina. As it is known that one of the factors of the formation of the State of Medina, resulting from the development of adherents of Islam who transformed into social groups and had real political power in post-Mecca period under the leadership of the Prophet.

Having ordered to emigrate by Allah SWT, in fact, it broughtgreat influence and impact both for the city of Medina itself and the position of the Prophet and his people. In the city that was originally named as Yathrib, they achieved good position and soon became strong and was able to stand on their own. ${ }^{3}$

In the context of the history of Islamic civilization, Medina is known as a proof of a milestone in the success of Prophet Muhammad in establishing justice, peace and civilization. So even today, this success is consideredas the pride of Muslims who at the same time can be a source of inspiration both for Muslims in particular and other people in general. In addition, it can be said that Medina is a beacon of civilization and a symbol of Muslims victory who can raise the spirit (ghiroh) of solidarity and pride among Muslims.

Medina has pluralistic social condition and heterogeneous society, so in order to arrange the community prophet Muhammad using some steps. The first steep was by arranging the intern life of the Muslims, namely by introducing or building relationship between people who perform the hijra (the Muhajirin) - the people who moved from Mecca to Medina - with the Anshar(Medina people who welcomed the Muhajirin) effectively.

At that time, the media used to unite the brotherhood was not a relationship of blood or tribes, but based on the bond of faith (religion) adopted. This led to the formation of Islamic community at that time so that this event, by Phillip K. Hitti in Pulungan,is called as the "miniature of the Islamic world". The second step pursued by the Prophet Muhammad in $622 \mathrm{AD}$ is to unite between the Muslims, Jews and other tribes through a written agreement which is known as the "Medina Charter".4

Medina Charter contains very important values, especially in terms of inter-citizen equality, religious freedom and security guarantees. These three things become very important valueswhich are fundamental values in the concept of democracy. This charter illustrates the relationship between Islam and other religion and tribes placed in the constitutional framework and laws, to organize the social and political life of Medina society.

It has been acknowledged by all parties that Medina Charter indeed contains the main ideas that is considered very amazing which is viewed from modern point of view. In that constitution, the ideas that now become the view of

3J. Suyuti Pulungan, Fiqih Siyasah, (Jakarta: Lembaga Studi Islam dan Kemasyarakatan, 1995), p. 79-81

${ }^{4}$ Ibid., p. 84 
modern life was formulated for the first time, such as freedom of religion, diversity, multi-culturalism, humanism and the right of each group to organize life in accordance with beliefs, independence of economic relations, and others. It also emphasized the existence of a general obligation, namely participation in joint defense efforts against external enemies, and uphold humanist values. ${ }^{5}$

On the basis of the principles contained in Medina Charter which has been implemented by the Prophet Muhammad and the ruling caliphs in running the government, it is interesting to be studied and researched further. In line with that, the researcher conducted a study or research on the principles of Islamic moderation in Medina Charter.

\section{Discussion}

\section{The concept of moderation in Islam}

Basically, the words of Islamic moderation for Muslims itself is not a strange thing anymore. Therefore, the term Islamic moderation is actually a translation of a word derived from Arabic which is al-Wasathiyyah ${ }^{6}$ alIslamiyyah. In connection with the word al-Wasathiyyah al-Islamiyyah, alQaradawi calls it with some equivalent words which has similar meaning. The words are Tawazun, I'tidal, Ta'adul and Istiqamah. ${ }^{7}$

Meanwhile, in the Qur'an, the word wasath and its derivation is called five times with a meaning that is in line with the meanings has been mentioned above. A commentator, Abu al-Su'ud, said that wasath initially pointed to something that became the meeting point of all sides like the center of the circle. Then the meaning of wasathis developed to be the human qualities which is possessed by human beings because those qualities becomes the center ofdespicable traits. ${ }^{8}$

The meaning of that word is also similar as contained in the hadith. Hence, an expert of the hadith vocabulary, Ibn al-Athir, when explaining the hadith which says "Khayru al-Umûri Awsâthuha" explained that every praiseworthy nature has two disgraceful sides (ends). According to him, the generosity is in the middle between miserly and wasteful, it is also in the middle between fear and recklessness. This is, of course, in line with the

5Bosco Karvallo dan Dasrizal, (ed). Aspirasi Umat Islam Indonesia, (Jakarta; Leppenas, 1983),

6The termWasatiyyahis actually derived from the word (وسط), which means middle or modest. Modesty is also usually known asal-iqtisad, al-Tawassut dan al-I"tidal (Mu'jam Wasitt.th). Besides that, Wasatiyyahis also defined as (أفضل وخيار) the best choice. Complete explanation, see alSalabi, Ali Muhammad, al-Wasatiyyah fil al-Quran al-Karim, (Beirut: Dar al-Marifah, 2005), p. 20

7The word Wasatiyyah in Kamus Istilah Media Melayu-Arab in line with i'tidal and mutawasit which means modest and the wordtasamuh which means tolerance. (Abd. Rauf 2005: 348 \& 416). It is also said by Yusuf al-Qaradhawi inKalimat fi al-Wasathiyyah wa Madlimiha, (Kairo: Dar al-Syuruq 2011), p. 13.

${ }^{8} \mathrm{Abu}$ al-Su'ud,Irsyâd al-Aql al-Salîm, 1/123 in Muchlis M. Hanafi,"Konsep Al-Wasathiyyah in Islam", in HARMONI: Jurnal Multikultural \& Multireligius, Vol. VIII, October - December 2009, p. 38. 
command of man to abstain from all the disgraceful qualities by liberating himself from that trait. The farther away he is from that trait, themore liberate he will be. The farthest position from either side / tip is the middle. Therefore, those who are in the middle will be kept away from the sides of the despicable. ${ }^{9}$ The same thing was also stated by Mohammad Hashim Kamali:

"Moderation or Wasațiyyah (Arabic synonyms: tawassuț, i tidāl, tawāzun, iqtisād), is closely aligned with justice, and it means opting for a middle position between extremities. Moderation is often used interchangeably with "average," "core," "standard," "heart," and "non-aligned." The opposite of wasatiyyah is tatarruf, which denotes "inclination toward the peripheries" and is known as "extremism," "radicalism," and "excess." In its Arabic usage, wasatiyyah also means the best choice such as in the hadith: "The Prophet [pbuh] was the best (awsat) of the Qurayshite descent."10

Basically, moderation or wasatiyyah ${ }^{11}$ is the Arabic synonym of tawassut, i'tidāl, tawāzun, iqtișādwhich is very closely and in harmony with justice and that means choosing to be in the middle position. Subsequently in turn, the word moderation is also often used with the terms "average", "core", "standard", "heart", and "non-block". The opposite of wasatiyyah is tatarruf, which characterizes as a "tendency toward the road" and is later known as "extremism", "radicalism" and "excess".12 As in the context of its use in Arabic, according to al-Farfur in Kamali, the word wasatiyyah also means the best choice such as hadith: "The Prophet is the best (awsat) descendant of the Qurays".13

Apparently, the definition of al-Wasathiyyah al-Islamiyyah as described previously, almost in every writing on Islamic Moderation, has always been adopted or taken as reference by Muslim thinkers and intellectuals. Although the description of the editorial differs from one to another, the essence and substance of the meaning are similar. However, one thing should be noted that in any form lafazh is used, its meaning will not go

\footnotetext{
9Ibn al-Atsir, Al-Nihâyah fî Gharîb al-Hadîts wal Atsar, 5/399 in Muchlis M. Hanafi, "Konsep Al-Wasathiyyah in Islam", in HARMONI: Jurnal Multikultural \& Multireligius, Vol. VIII, October December 2009, h. 39

10Mohammad Hashim Kamali, The Middle Path of Moderation in Islam The Qur'annic Principle of Wasatiyyah, (The United States of America by Oxford University Press, 2015), p. 9

11 The word "moderate" is derived from Arabic consisting of three letters which means approaching to each other. That word can be read in two versions. Tawassuth which is usually defined as "attitudes" (ط-س-و) The first version, "وطس "وط" the letterSin is read assukun,as the preposition word which means "between". Whereas the second version, "وطس" the letter Sin is read asfathah, which has some meanings: (1) Between two ends (in the middle of two ends); (2) character which means "the best"; (3) fair or justice; (4) between the good and the bad.

${ }^{12}$ Another term for the word eksremism in Arabic is al-ghuluw, al-ifrät, and "exceeds the limit."

13Muhammad 'Abd al-Lațīf al-Farfūr, Al-Wasațiyyah fíl-Islām, (Amman: Dāral-Nafā'is, 1409/1988), p. 71, in Mohammad Hashim Kamali, The Middle Path of Moderation in Islam The Qur'ānic Principle of Wasațiyyah..., p. 9
} 
beyond the meaning of "justice, glory, goodness, mid, intermediate, and modest."14

Based on some understanding that has been decomposed above it can be concluded that the word wasath (middle) which has a good and commendable meaning of course contrary to the word edge (altharf) which connotes negatively because its existence on the edge may cause someone to slip. The religious attitudes of the tawassuth (mid) contrast with the tatharruf (edges / ends), both on the left and right ends.

Whereas in modern Arabic, the word tatharruf itself connotes the meaning of radical, extreme and exaggerated. The word tatharruf which describes such attitudes is not found in the Qur'an or hadith. Such attitude in the Qur'an is expressed with the word alghuluww which means as follows:

Say, "O People of the Scripture, do not exceed limits in your religion beyond the truth and do not follow the inclinations of a people who had gone astray before and misled many and have strayed from the soundness of the way."

Thus, it can be interpreted that Islamic moderation is a point of view or attitude to always try to put yourself in the middle position of two opposite and excessive attitudes. So one of the two attitudes is not dominating each other. Such attitude, by Abd. Rauf Muhammad Amin, is referred to as a moderate Muslim, i.e., a Muslim who gives any value or aspect in a proper portion for both sides. ${ }^{15}$ As to which al-Qaradawi has mentioned, for man whoever he is - is unable to free himself from the influence and bias of his traditions, thoughts, family, times and places in running his life, it is impossible to represent or offer full moderation in the real world. Again only Allah Almighty is able to do that. 16

\section{Universality and Moderation of Islam}

Before we further discuss Islam as a thought or doctrine, it would be nice if we start this elaborationby seeing Islam from the aspect of the language. The word "Islam" comes from the Arabic word taken from the word "salima" which means "safe". Then from the word "salima" is formed the word "aslama" which means "surrender, submissive, obedient, and loyal".

Furthermore, the word "aslama" itself becomes the main point of Islam, which contains all meanings as its fundamental meaning. That is because a person who does "aslama" or convert to Islam are called Muslim, in other words, the person has stated that he is obedient, surrender, and submissive to Allah SWT. So that it can be said by carrying out "aslama", then the person is guaranteed salvation in the world and in the hereafter. Furthermore from the word "aslama", other words are also formed namely, the word "silmun"

14Edi Junaidi, “Kamus Syari'ah Tawassuth (Moderat)" dalam Majalah Bimas Islam, Jakarta: Kementerian Agama RI, Edisi No. 3/III/2015, p. 68

${ }^{15} \mathrm{Abd}$. Rauf Muhammad Amin, "Prinsip dan Fenomena Moderasi Islam dalam Tradisi Hukum Islam", Jurnal Al-Qalam, Volume 20, Edisi Khusus Desember 2014, p. 25.

16Yusuf al Qaradhawi, Kalimat fi al-Wasathiyyah wa Madlimiha..., p. 13. 
and "salamun" which means "peace". So, Islam is understood as a peaceloving doctrine. Therefore a man who claims to be a Muslim is to be at peace with God and with his fellow human beings. ${ }^{17}$

In addition, regarding this matter, Harun Nasution said that Islam is a religion whose teachings are revealed by God to the mankind through Prophet Muhammad SAW. ${ }^{18}$ Islam was born in Mecca, brought by Prophet Muhammad SAW as God's Apostle to guide human beingsin passing through the straight path. After the Prophet's death, the relay of Islamic leadership was upheld by his companions known as "Khulafaur-Rashidin", at that time Islam began to grow rapidly due to the expansion undertaken by later Islamic daulah(reign), such as the Abbasidand Umayyad. Islamic teachings were then widespread to the areas outside the Arabian peninsula. So, the teachings of Islam soon met with various civilizations and local culture that had been rooted for centuries.

Islam with the message brought by Prophet Muhammad SAW is a religion that contains a fundamental understanding. Islam is not only the property of its individual or proprietary carrier and is destined for a particular class or country. Islam is a universal religion which is a realization of the concept of grace for the whole nature (Rahmatan lil Alamin). ${ }^{19}$ It is clear that the message of Islam is not only for mankind, but more broadly than that, that is mercy for the whole nature.

In response, Nurcholish Madjid said that Islamic teachings are intended for the whole mankind, because the Prophet Muhammad is the messenger of God for all mankind. ${ }^{20}$ In other words, the teachings of Islam apply to all human beings on this earth, and not limited to Arabs alone, but to all nations on the same level. Then, it is clear if the values of the universal teachings of Islam are applicable at any time and place and valid for all groups or human beings, can not be limited by formalism, such as a formalism "facing east or west" (i.e., ritualistic formalism generally). ${ }^{21}$

According to Muhammad Tholhah Hasan, the characteristics of Islam can be seen in various concepts it carries, namely:22

First, the concept of Islamic theology that is based on the principle of monotheism as the concept of monotheism with the highest level. This

17Didiek Ahmad Supadie dan Sarjuni (ed), Pengantar Studi Islam (Jakarta: Raja Grafindo Persada, 2011), p. 71-72.

${ }^{18}$ Harun Nasution, Islam, ditinjau dari berbagai aspeknya, Jilid 1,(Jakarta: Bulan Bintang, 1974), p. 17

${ }^{19}$ Amin Syukur, Pengantar Studi Islam,(Semarang: Pustaka Nuun, 2010), p. 30

${ }^{20}$ Nurcholish Madjid, Islam Doktrin dan Peradaban: Sebuah Telaah Kritis Tentang Masalah Keimanan, Kemanusiaan, dan Kemoderenan, (Jakarta: Yayasan Wakaf Paramadina, 1992), p. 360-361.

21Ibid., h. 362

${ }^{22}$ Muhammad Tholhah Hasan, Islam dalam Perpektif Sosio Kultural, (Jakarta: Lantabora Press, 2004), p. 4-5. 
concept of monotheism gives birth to the insight of moral unity, social unity, ritual unity and even the unity of cultural identity.

Second, the concept of human status, in relation to God (hablumminallah), his relationship with his fellow human beings (hablumminannas), even the whole fellow beings, as well as his relationship with the universe. These relationships are in the network of worship and kekhalifahan (Islamic reign), namely the function of worship and khilafah function.

Third, the concept of science as an integrative part of human life. The first revelation of the Qur'an in addition to make the khalaqalinsan declaration (He has created man) also declared 'alamal insan (He taught man). This human besides being created by Allah, also given scientific intelligence. This concept is related to God's promise of "what is in the heavens and on earth in the designation of man".

Fourth, the concept of worship in Islam. Besides touching the aspects of ritual, it also touches on social aspects as well as cultural aspects in life.

Based on the above description, then by borrowing a term from Harun Nasution in Parsudi, that religion (Islam) essentially contains two groups of teachings. The first group, who believes that the revelation of God, is absolute, eternal, unchanging and unchangeable. While the second group, those who believes that the revelation of God requires an explanation of the meaning and implementation. Therefore, the explanation is essentially not absolute, relative, and can be changed in accordance with the development of time or culture. ${ }^{23}$

Meanwhile, Nurcholish Madjid in Yustion revealed that between religion (Islam) and culture are two indivisible but inseparable fields. Religion is absolute, unchanged according to time and place. But in contrast to culture, though based on religion, it can change from time to time and from place to place. Most cultures are based on religion, but never otherwise, religion based on culture. Therefore, religion is primary, and culture is secondary. Culture can be an expression of religious life, because it is subordinate to religion. ${ }^{24}$

Islam is stated as a religion because it is really the product of Allah SWT which includes syariah and figh (law) where they are both derived from the Qur'an and al-Hadith. Syariah and figh, taught by Islam, have played their respective roles in filling the life of human on this earth. Syariah reflects Islam as a religion, while figh reflects Islam as a culture. This statement is based on the opinion of Khaled Abu el-Fadl in Kunawi Basyir that syariah is

23Parsudi Suparlan (ed), Pengetahuan Budaya, Ilmu-Ilmu sosial dan Pengkajian MasalahMasalah Agama, (Jakarta: Pusat Penelitian dan Pengembangan Lektur Agama Badan Litbang Agama, 1982), p.18.

${ }^{24}$ Yustion dkk., Islam dan Kebudayaan Indonesia: Dulu, Kini, dan Esok, (Jakarta: Yayasan Festival Istiqlal, 1993), p. 172. 
God's will in an abstract and ideal form, while figh is the result of human effort to understand the God's will. ${ }^{25}$

Furthermore, the Holy Qur'an as the revelation of Allah which is also the holy book of Muslims and is the best source of Islamic teachings and cannot be replaced. Because Muslims believe that the Holy Qur'an is the source of absolute truth. Nevertheless, borrowing the term from Quraish Shihab in Dadang, that absolute truth will not be seen, when the Qur'an does not interact with social reality, or if it is not earthed: read, understood, and practiced. The point is that when the absolute truth is addressed by its adherents with different cultural background or level of knowledge, partial truths will be emerged, so that the absolute truth remains God's. ${ }^{26}$

The above description is very clear, if the Holy Qur'an is the revelation of Allah which becomes the highest and absolute source Islamic teachings. However, the absolute truth will only be meaningful if it makes contact and communicates with the phenomenon and social reality that exists on this earth. At this position the absolute truth will evolve into partial truths, because the stages of the internalization process to the adherents of the absolute truth is influenced by the existence of different social settings, paradigms of thinking and background knowledge of its adherents.

Despite the birth of partial truths, we can not deny, for any reason, the the absolute truth is really originated and only belongs to Allah SWT. The level of absolute truth is what we are often called asSyariat Islam. While the emergence of partial truth resulting from the struggle of social reality in the society is counted as relative. This relativity is called asfigh. On this basis, it is not surprising that the partial truth is easily changed depending on the circumstances and conditions that follow.

In response to this case, Ahmad Wahib describes that the change of understanding will change. This happens not because the object is changing, but because the subject or one's brain that observes the object is different way. 27 However, according to Morris, the existence of Islam, among others, is strongly influenced by the social environment in which it grows and develops. ${ }^{28}$ As revealed by Moeslim Abdurrahman that the dynamics of Islam in the cross-history of civilization of mankind is determined by social

${ }^{25}$ Kunawi Basyir, Islam dan Budaya Lokal, (Surabaya: UIN Sunan Ampel Press, 2014), p. 15.

26Dadang Kahmad, Sosiologi Agama, (Bandung: Rosdakarya, 2000), p. 172.

${ }^{27}$ Ahmad Wahib, Pergolakan Pemikiran Islam, (Jakarta: Democracy Project Yayasan Abad Demokrasi, 2012), p. 3.

${ }^{28}$ As Morris said, this happens if it is vewed from sociological point of view, Islam is considered as socio-cultural phenomenon. In the dynamics of space and time, Islam that originally serves as a subject on the level of real life applies as an object and simultaneously applies to it various social laws. For complete explanation, see Brian Morris, Antropologi Agama: Kritik TeoriTeori Agama Komtemporer, (ter). Imam Khoiri (Yogyakarta: AK Group, 2003), p. 393. 
struggle which will ultimately be very influential in giving color, style, and character of Islam. ${ }^{29}$

Once again, judging from historical perspective, especially in the context of Indonesia, Islamic teachings have been accomodated by local culture which happened during the early historical period of Islamic development in Indonesia. ${ }^{30}$ As a religion, Islam appears so perfects, by offering and bringing the norms and the rules of new life whichis very different compared to the teachings of other religions that came previously. Furthermore, if there is a connection between Islam and culture then there are two important conceptions that need to be clarified in order to avoid confusion. The two conceptions are Islam as a socio-cultural consensus, and Islam as a cultural reality.

Conception between Islam and Culture, in the Azyumardi Azra ${ }^{31}$ point of view, is often known as great tradition. At the level of Islam as a cultural conception, the great tradition (Islam) is in the form of original permanent Islamic doctrines, or at least an interpretation firmly attached to the basic teachings of Islam. Meanwhile, Islam as a cultural reality is known aslittle tradition or local tradition or Islamicate, "Islamic" areas, which are influenced by Islam. In a smaller space this doctrine is embodied in the conception of faith and syariah-Islamic law - that inspires the mindset and acts of Muslims.

\section{Conclusion}

Based on the explanations and descriptions that the author has explained above, it can be concluded that the Medina Charter in Medina social life contains the life principles and foundations of the society. The principles underlying the Medina Charter include: (a) The principle of the unity of the humankind; (B) social solidarity; (C) protection and defense of the weak and oppressed; (D) social justice; (E) peace between peoples and the environment; $(\mathrm{F})$ equality before the law; $(\mathrm{G})$ freedom of opinion, association and religion; $(\mathrm{H})$ upholding human rights; (I) nationalism; (J) deliberation.

Furthermore, the application of the principles written in the Medina Charter does not recognize the category of dichotomy among human beings, i.e., between Muslims and other citizens equally recognized by civil rights, not one group is privileged.

${ }^{29}$ As an indication, explained by Moeslim Abdurrahman that in various parts of the world, Islam has experienced the peak of the glory of civilization, but it is undeniable that in some other places, Islam actually suffered a setback and even drowned by the changing times. For complete explanation, see Moeslim Abdurrahman, "Ber-Islam Secara Kultural", Islam Sebagai Kritik Sosial, (Jakarta: Erlangga, 2003), p. 150.

30Syarifuddin Jurdi, Sejarah Wahdah Islam: Sebuah Geliat Ormas Islam di EraTransisi, (Yogyakarta: Kreasi Wacana, 2007), p. 6

${ }^{31}$ Azyumardi Azra, Konteks Berteologi di Indonesia: Pengalaman Islam, (Jakarta: Paramadina, 1999), p. 13 
Whereas in the principle of democracy, basically the Medina Charter is made to give freedom to all groups, because one of the cores of Islamic spirit is to realize social justice so that the Holy Qur'an teaches humanity to fight against injustice and oppression of freedom. Because, people are free to embrace beliefs which they like and do according to their will. Democracy, in addition to the implementation and the principle of social equality and the absence of striking differences, also becomes a way of life. A way of life that emphasizes the value of individuals and intelligence and human's belief that in doing life activities might show social relationship that reflects the existence of mutual respect, cooperation, tolerance and fair play.

As for the principle of tolerance (tasamuh): respect for religion, Medina Charter contains the principle of tolerance, where Muslims are ready and able to interact and communicate with the Jews. They have the protection and freedom to practice their respective religions.

\section{Reference}

Fiqih Siyasah, Jakarta: Lembaga Studi Islam danKemasyarakatan, 1995
Al-Kahashấish al-Âmmah li al-Islâm, Kairo: Maktabah Wahbah, Cet. IV, 1996

At-Tafsir al-Wajiz 'ala Hamisyi al-Qur'an al-'Adhim. Cet. II, Damaskus: Daar al-Fikr, 1996

, Kalimaat fi al-Wasatiyyah al-Islamiyyah wa Ma'alimuha, Kuwait: al-Markaz al-Alami Lilwasatiyyah, 2007.

, Ushul an-Nidham al-Ijtima'i fiy al-Islam, Cet. II Asy-Syirkah at-Tunisiah,tt

"Islam-Konflik dan Piagam Perdamaian" dalam http://ruhullah.wordpress.com diakses tanggal 19 November 2016

Abd. Rauf Muhammad Amin, "Prinsip dan Fenomena Moderasi Islam dalam Tradisi Hukum Islam”, Jurnal Al-Qalam, Vol. 20, Edisi Khusus Desember 2014

Abdul Wahhab Khallaf, Kaidah-Kaidah Hukum Islam (Ilmu Ushul-Fiqh), Jakarta: Rajawali Pers, 1985

Abu 'Usman 'Amr bin Bahr, Tahdzib al-Akhlak, Cet. I., Daar as-Shahabah,1989

Abu al-Su'ud,Irsyâd al-Aql al-Salîm, 1/123 dalam Muchlis M. Hanafi, "Konsep AlWasathiyyah dalam Islam", dalam HARMONI: Jurnal Multikultural $\mathcal{E}$ Multireligius, Vol. VIII, Oktober - Desember 2009

Ahmad Sukardja, Piagam Madinah Dan Undang-Undang Dasar 1945: Kajian Perbandingan Tentang Dasar Hidup Bersama Dalam Masyarakat Yang Majemuk, Jakarta: UI Press, 1995

Ahmad Wahib, Pergolakan Pemikiran Islam, Jakarta: Democracy Project Yayasan Abad Demokrasi, 2012

Ali Ash-Shabuni, Shafwah at-Tafasir, Juz. II. Cet. IV., Bairut: Daar Al-Qur'an alKarim, 1981

Ali Muhammad al-Salabi, al-Wasatiyyah fil al-Quran al-Karim, Beirut: Dar alMarifah, 2005

Amin Syukur, Pengantar Studi Islam, Semarang: Pustaka Nuun, 2010 
Amirul Hadi dan Haryono, Metodelogi Penelitian Pendidikan, Bandung: Pustaka Setia, 1998, cet. Ke-1.

Anselm Strauss \& Juliet Corbin, Basic of Qualitative Research Grouded Theory Procedures and Techniques, Muhammad Shodiq \& Imam Muttaqien (Penterjemah), Dasar-dasar Penelitian Kualitatif Tatalangkah dan Teknikteknik Teoritisasi Data, Yogyakarta: Pustaka Pelajar, 2003

Anton Bakker, Metode-metode Filsafat, Jakarta: Ghalia Indonesia, 1984

Azyumardi Azra, Konteks Berteologi di Indonesia: Pengalaman Islam, Jakarta: Paramadina, 1999

Bosco Karvallo dan Dasrizal, (ed). Aspirasi Umat Islam Indonesia, Jakarta; Leppenas, 1983

Brian Morris, Antropologi Agama: Kritik Teori-Teori Agama Komtemporer, (ter). Imam Khoiri, Yogyakarta: AK Group, 2003.

Dadang Kahmad, Sosiologi Agama, Bandung: Rosdakarya, 2000

Deddy Mulyana, Metodelogi Penelitian Kualitatif: Paradigma Baru Ilmu Komunikasi dan Ilmu Sosial Lainnya, Bandung: Remaja Rosdakarya, 2003

Didiek Ahmad Supadie dan Sarjuni (ed), Pengantar Studi Islam, Jakarta: Raja Grafindo Persada, 2011

Edi Junaidi, “Kamus Syari'ah Tawassuth (Moderat)” dalam Majalah Bimas Islam, Jakarta: Kementerian Agama RI, Edisi No. 3/III/2015

Harun Nasution, Islam Ditinjau Dari Berbagai Aspeknya, Jilid 1, Jakarta: Bulan Bintang, 1974

Hasbiyallah, Fiqih dan Ushul Figh, Bandung: Remaja Rosdakarya, 2013

Ibn al-Atsir, Al-Nihâyah fî Gharîb al-Hadîts wal Atsar, 5/399 dalam Muchlis M. Hanafi, "Konsep Al-Wasathiyyah dalam Islam", dalam HARMONI: Jurnal Multikultural \& Multireligius, Vol. VIII, Oktober - Desember 2009

Ibn Hisyam, As-Sìrah an-Nabawiyah, Al-Qāhirah: tt.

Imam Suprayogo dan Tobroni, Metodologi Penelitian Sosial-Agama, Bandung: Remaja Rosdakarya, 2001

J. Suyuthi Pulungan, Prinsip-Prinsip Pemerintahan dalam Piagam Madinah Ditinjau dari Pandangan Al-Qur'an, Jakarta:Rajawali Pers, 1993

James A. Black, Metode dan Masalah Penelitian Sosial, Bandung: Refika Aditama, 2001

Kunawi Basyir, Islam dan Budaya Lokal, Surabaya: UIN Sunan Ampel Press, 2014

Lexy J. Moleong, Metodologi Penelitian Kualitatif Edisi Revisi, Bandung; Rosda Karya, 2011

M. Yakub, "Piagam Madinah: Acuan Dasar Negara Islam" dalam Analytica Islamica, Vol. 6, No. 2, 2004.

M.A. Salahi, Muhammad Sebagai Manusia dan Nabi, (Terj) M. Sadat Ismail, Yogyakarta; Mitra Pustaka, 2006.

Masri Singarimbun, Metode Penelitian Survey, Jakarta: LP3ES, 1989

Moeslim Abdurrahman, "Ber-Islam Secara Kultural", Islam Sebagai Kritik Sosial, Jakarta: Erlangga, 2003

Mohammad Hashim Kamali, The Middle Path of Moderation in Islam The Qur'anic Principle of Wasatiyyah, The United States of America by Oxford University Press, 2015

Monawwar Khalil, Kelengkapan Tarikh Nabi Muhammad, Jakarta: Gema Insani Press, 2001 
Muhammad 'Abd al-Lațîf al-Farfūr, Al-Wasațiyyah fíl-Islām, Amman: DāralNafā'is, 1409/1988, dalam Mohammad Hashim Kamali, The Middle Path of Moderation in Islam The Qur'anic Principle of Wasatiyyah, The United States of America by Oxford University Press, 2015

Muhammad Abu Zahra, Ushul Figh (Ushul al Fiqih), terj. Saefullah, et.Al., cet.5 Jakarta: Pustaka Firdaus, 1999.

Muhammad Thahir bin 'Asyur, Maqashid Syari'at al-Islamiyyah, Daar an-Nafa-is, tt Muhammad Tholhah Hasan, Islam dalam Perpektif Sosio Kultural, Jakarta: Lantabora Press, 2004

Muslim bin Hajjaj al-Qusairiy an-Naisaburiy, Shahih Muslim, Kitab Birr wa Shilah, Bab Nahyi 'an La'ni ad-Dawab wa ghairih, No. hadis. 2598, Cet. I Riyadh: Daar at-Tayyibah,2006

Nurcholish Madjid, Islam Doktrin dan Peradaban: Sebuah Telaah Kritis Tentang Masalah Keimanan, Kemanusiaan, dan Kemoderenan, Jakarta: Yayasan Wakaf Paramadina, 1992

Parsudi Suparlan (ed), Pengetahuan Budaya, Ilmu-Ilmu sosial dan Pengkajian Masalah-Masalah Agama, Jakarta: Pusat Penelitian dan Pengembangan Lektur Agama Badan Litbang Agama, 1982

S. Margono, Metodologi Penelitian Pendidikan, Jakarta: Rineka Cipta, 2003

Said Agil Husin Al-Munawar, Al-Qur'an Membangun Tradisi Kesalehan Hakiki, Jakarta: Ciputat Press, 2002

Suharsimi Arikunto, Prosedur Penelitian Praktis, Jakarta: Bina Aksara, 1983

Supriyanto, "Perdamaian dan Kemanusiaan dalam Pandangan Islam", Kalam: Jurnal Studi Agama dan Pemikiran Islam, Vol. 7, No. 2, Desember 2013

Syarifuddin Jurdi, Sejarah Wahdah Islam: Sebuah Geliat Ormas Islam di Era Transisi, Yogyakarta: Kreasi Wacana, 2007

Tim Penyusun Kamus Bahasa Indonesia Departemen Pendidikan dan Kebudayaan, Kamus Besar bahasa Indonesia, Jakarta: PT Gramedia, 1989

W. Harris and Judith S Levey, The New Columbia Encyclopedia, New York \& London: Columbia University Press, 1975

W. Montgomery Watt, Islamic Political Thought, Edinburgh: Edinburgh University Press, 1968

Wahbah Zuhaili, Al-Wajiz fiy Ushul al-Figh, Cet. I., Bairut: Daar al-Fikr alMu'ashir,1999

Wila Huky, Pengantar Sosiologi, Surabaya: Usaha Nasional, 1986

Yatimin Abdullah, Studi Islam Kontemporer. Cet. I., Jakarta: Amzah, 2006

Yustion dkk., Islam dan Kebudayaan Indonesia: Dulu, Kini, dan Esok, Jakarta: Yayasan Festival Istiqlal, 1993

Yusuf al-Qaradhawi dalam Kalimat fi al-Wasathiyyah wa Madlimiha, Kairo: Dar alSyuruq 2011 